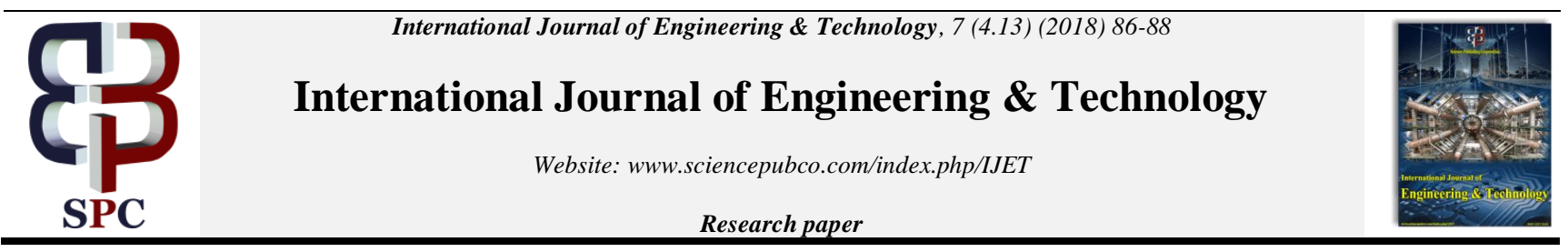

\title{
The needs of aircraft avionics' radio line replaceable unit repair center at UniKL MIAT
}

\author{
Muzzaffar Wasi Zainal Ariffin*, Muhd Khudri Johari, Hashim Ibrahim \\ Universiti Kuala Lumpur - Malaysian Institute of Aviation Technology, Dengkil, Selangor, Malaysia \\ *Corresponding author E-mail: muzaffarwasi@unikl.edu.my
}

\begin{abstract}
For the local aircraft maintenance industry, radio line replaceable unit (LRU) has been essential in aircraft's airworthiness but at the same time, costly for many Malaysian aviation companies. This study analyzes the survey conducted with 66 aviation industry personnel from 11 local aviation companies, which have had to spend a considerable amount of financial budget on their LRU maintenance every year. The conclusion from the survey data shows that most of them agreed on the need to establish an LRU Center in a local approved training organization such as Universiti Kuala Lumpur - Malaysian Institute of Aviation Technology (UniKL MIAT) because of several justifiable reasons such as significantly cheaper costs, more hands-on training and job opportunities, shorter delivery time, and possible research and development benefits.
\end{abstract}

Keywords: avionics; radio line replaceable unit; aircraft maintenance; DCAM; CAAM; needs analysis; UniKL MIAT.

\section{Introduction}

Aircraft maintenance, which requires skilled technicians and specialized instruments, is a necessary process for the flight operation. Maintenance and repairs must not only be accomplished inside the aircraft maintenance hangars within a period of time but they also have to meet the standards to ensure air traffic safety. Flight schedules and aircraft maintenance schedules are closely related. It is thus essential for airlines to efficiently and effectively perform the maintenance scheduling during routine operations. There are three types of aircraft maintenance scheduling plan: long-term, midterm and short-term that take place in the aircraft maintenance hangars. A training center, especially in aircraft maintenance licensing and qualifications, is a business orientated company such as Universiti Kuala Lumpur - Malaysian Institute of Aviation Technology (UniKL MIAT) is required to obtain the approval from Department of Civil Aviation's (DCA) before it can operate in Malaysia [1]. All requirements in training center will be in accordance to Part 147 - Approved Maintenance Training Organization (ATO).

As a business entity, UniKL MIAT needs to take this opportunity and initiates a training center development for financial developments [2]. Specifically, for this study, researchers have taken into context about academic recommendation on establishing an overhaul center in Malaysia [3] and gradually decided to focus on the development of the Line Replaceable Unit (LRU) repair center in UniKL MIAT. As financial trends of both private education sector and market industry in Malaysia fluctuate constantly, this definitely is a challenge but it is significant for the betterment of the company [4]. Opportunity to establish a Line Replaceable Unit Center (LRUC) for aviation industries in Malaysia is possible if the market studies highlight the urgent needs and problems that arise from unavailability of LRUC. UniKL MIAT is producing license engineer in all trades and this is a good opportunity for business if the
LRUC for aircraft avionics can be established. This is mainly due to the absence of such center in Malaysia. Though Malaysia Airline System (MAS) does provide this type of service, their LRU department has been downsized and it is unattainable for them to assist on LRU services or repair for all external local and international aircraft. The status of UniKL MIAT as a training center under Part 147 has been substantially approved by DCA. However, in order to become an LRUC, UniKL MIAT requires another type of DCA approval to be under the Part 145 - Maintenance Organization Approval as the Maintenance, Repair and Overhaul (MRO) organization only for LRUC.

At present, LRU services for Malaysian commercial airlines have been conducted by their licensed engineers within their own maintenance hangars. This is why UniKL MIAT has focused on smaller aviation industrial companies. Table 1 shows that these companies have no choice but to outsource their LRU maintenance to the Singapore's LRUCs. This is because not only they do not have the capacity in terms of sufficient manpower or necessary workshops, it is also cheaper than establishing their own repair center with the needed engineering personnel.

\section{Line replaceable unit}

Every aircraft produced would typically have LRUs built-in within its compartment. They are delicately designed for the purpose of being able to be changed or removed at a quick rate. An LRU is a sealed black box, which contains instruments such as radio or the other auxiliary equipment [9]. LRU can be generally divided into three types: very high frequency communication (VHF), high frequency communication (HF) and instrument landing system (ILS). 
Table 1: LRU service details by 11 Malaysian aviation companies (adapted from Khairuddin et al. [3])

\begin{tabular}{|c|c|c|c|c|}
\hline Company & $\begin{array}{c}\text { Number } \\
\text { of } \\
\text { Aircraft }\end{array}$ & $\begin{array}{c}\text { Repair } \\
\text { cost } \\
\text { (RM) }\end{array}$ & $\begin{array}{c}\text { Transport } \\
\text { Cost (RM) }\end{array}$ & $\begin{array}{c}\text { Delivery } \\
\text { time } \\
\text { (days) }\end{array}$ \\
\hline Company M & 32 & 128,000 & 16,000 & 7 \\
\hline Company H & 25 & 100,000 & 12,500 & 7 \\
\hline Company A & 41 & 164,000 & 20,500 & 7 \\
\hline Company S & 9 & 32,000 & 4,500 & 7 \\
\hline Company A1 & 12 & 48,000 & 6,000 & 7 \\
\hline Company F & 6 & 24,000 & 3,000 & 7 \\
\hline Company I & 13 & 52,000 & 6,500 & 7 \\
\hline Company C & 6 & 24,000 & 3,000 & 7 \\
\hline Company A2 & 3 & 12,000 & 1,500 & 7 \\
\hline Company P & 4 & 16,000 & 2,000 & 7 \\
\hline Company C2 & 57 & 228,000 & 28,500 & 7 \\
\hline
\end{tabular}

VHF communication systems are utilized more commonly to ensure the smooth flow of air traffic at the airports [5]. Since every aircraft would have this built-in instrument, pilots can receive the necessary instructions and further details from the authorities involved such as air traffic control towers [6]. The frequency range of the standard VHF is between 30 to $300 \mathrm{MHz}$, which can cover three to ten meters distance. However, the range for civil aviation is limited from $118-137 \mathrm{MHz}$. On the other hand, for communication processes that require longer distances, HF communication equipment is a better choice as they can cover up to 10 decameters. Airlines also utilize it for their necessary communication with the ground stations [7]. 3 to $30 \mathrm{MHz}$ would best describe a HF's radio frequency range with the communication distance of one to ten decameters. Meanwhile, to guide an aircraft from several kilometers out to the runway threshold, a system providing lateral and vertical guidance is used. The lateral guidance part is called as the localizer and the vertical guidance part is known as glideslope. In addition to localizer and glideslope signals, there are also marker transmitters that provide pilots with an indication of their approximate position at few intervals along the approach path [8]. These components, with their specific setup, would have varied frequency ranges and communication distances.

Many LRUs for commercial aircraft are designed according to the Aeronautical Radio Incorporated (ARINC) specifications, a company owned by several airlines that sell specifications and designates standards. Aside from ARINC, major aircraft manufacturers also have their own corporate definitions of LRU. These manufacturers include Boeing, Airbus and several military-linked corporations and industry players. If the system detects an LRU malfunction, the technicians will change the defected unit with new replacement. This is the reason why airlines' engineering complexes would have plenty of spares. After all, LRUs have been designed to be easily removed [9].

Long before DCA is upgraded to Civil Aviation Authority of Malaysia [10], the government's aviation agency has published the Civil Aviation Act 1996 of Malaysia under these regulations, concerning the necessary guidance for the establishment of an LRUC - where all regulations must be fulfilled [1].

- Regulation 28: Certificate of Maintenance Review

- Regulation 29: Technical Log

- Regulation 30: Inspection, overhaul, repair, replacement and modification

- Regulation 31: Licensing of Maintenance Engineer LRU maintenance is clearly stated under DCA's Annex 57A that is stating the lack of adequate control of Field Loadable Software (FLS) by operators can potentially result into safety related occurrences. FLS, being Loadable Software Aircraft Part (LSAP), together with Databases and user Modifiable Software (UMS), are firstly delivered with the new aircraft and contained in the Target Hardware and media sets in binders or storage bins. It should be realized that the part number of Target Hardware does not necessarily specify the loaded software part number. This aspect needs to be borne in mind when replacing affected LRUs [11]. The purpose of this Airworthiness Notice is to provide guidance for operators and maintenance organizations on the configuration management, procurement, embodiment and tracking of the aircraft Field Loadable Software to ensure continued airworthiness and operating safety standards are met. The guidelines have shown that like other aircraft parts, LRUs are equally important when it comes to aircraft maintenance. Hence, UniKL MIAT is taking the initiative to establish a very first LRUC in Malaysia. With the current facilities and manpower, it is believed that this can be not just an excellent business opportunity as a private university but also a training platform for students and staffs. With the objective to confirm this notion, a random survey has been carried out by seeking responses from personnel who are currently working at major aircraft maintenance industry players in Malaysia.

\section{Methodology}

The random sampling method is chosen because the questionnaire consists of 20 Likert-scale opinioned statements that reflect both the idea of establishing an LRUC in the ATO environment and its possible market demands in Malaysia. Contacts have been made with 11 aviation companies that have LRU maintenance as one of their key annual spending for the maintenance of their aircraft. All in all, only 66 out of the targeted 100 participants have managed to follow through with the appointments and sit down face-to-face to complete the survey. With the full permission from their direct supervisors, these participants are instructed to answer a two-part, 20 multiple-choice questions with a Likert-scale options ranging from "1" being "Strongly disagree" to "5" being "Strongly Agree". Table 2, Table 3 and Table 4 indicate the demographic profiles of the survey participants.

Table 2: Role of participants

\begin{tabular}{|c|c|c|}
\hline Role & Frequency & \% \\
\hline Management & 13 & 19.7 \\
\hline Engineers & 18 & 27.2 \\
\hline $\begin{array}{c}\text { Non-management (Administra- } \\
\text { tion) }\end{array}$ & 23 & 34.9 \\
\hline Non-management (Technicians) & 12 & 18.2 \\
\hline Total & 66 & 100 \\
\hline
\end{tabular}

Management consists of company managers, directors, university deans and also deputy deans. Engineers corresponds to the highranked aircraft maintenance personnel who have the authority to release the aircraft for flying. Administration refers to quality control executives, human resource staffs and business department personnel. Lastly, Technicians are lower-ranked aircraft maintenance personnel who do not have the authority to release aircraft for flying.

Table 3: Years of service of participants

\begin{tabular}{|c|c|c|}
\hline Years & Frequency & \% \\
\hline Below 5 Years & 8 & 12.1 \\
\hline 5-10 Years & 23 & 34.9 \\
\hline More Than 10 Years & 35 & 53 \\
\hline Total & 66 & 100 \\
\hline
\end{tabular}

More than 10 years personnel do not just have professional working experience but also the wisdom in foreseeing the industry as a whole. They also have more in-depth information regarding policies and aviation market situations as most of these data are not public.

Table 4: Educational background of participants

\begin{tabular}{|c|c|c|}
\hline Education & Frequency & \% \\
\hline Doctorate & 5 & 7.6 \\
\hline Master & 20 & 30.3 \\
\hline Bachelor Degree & 18 & 27.3 \\
\hline Diploma & 8 & 12.1 \\
\hline Professional certificate & 15 & 22.7 \\
\hline Total & 66 & 100 \\
\hline
\end{tabular}


Doctorate personnel differs greatly from others in terms of academic proficiency. This, however, does not mean that the opinions of others are of less worthy. Aviation industry does not necessarily require a higher level of academic qualification as hands-on and practical skills are more important, particularly when it comes to aircraft maintenance. Hence, there have been many aircraft maintenance personnel currently pursuing their higher education.

\section{Analysis and discussions}

The first part consists of statements pertaining the actual needs of an LRUC in Malaysia and the analysis has been compiled in Table 5. The second part of the survey emphasises on the problems faced because of the absence of an LRUC in Malaysia as shown in Table 6. The correlation test conducted shows that the value of Pearson' correlation (r) is 0.76 . This indicates that there is significant correlation between the needs of LRUC and the problems raised without existence of LRUC in Malaysia.

Table 5: The needs of an LRUC in Malaysia

\begin{tabular}{|c|c|c|c|}
\hline No. & Statement & Mean & Indicator \\
\hline 1 & $\begin{array}{l}\text { Majority of aviation } \\
\text { companies did not have specialist } \\
\text { on maintaining or repair the LRU } \\
\text { unit }\end{array}$ & 3.67 & Agree \\
\hline 2 & $\begin{array}{l}\text { There are not many LRU special- } \\
\text { ists in Malaysia on maintaining or } \\
\text { repairing the LRU unit }\end{array}$ & 3.79 & Agree \\
\hline 3 & $\begin{array}{l}\text { There are a few available LRU } \\
\text { centre in Malaysia }\end{array}$ & 4.14 & $\begin{array}{l}\text { Strongly } \\
\text { Agree }\end{array}$ \\
\hline 4 & $\begin{array}{l}\text { There are many aircraft to be } \\
\text { serviced on LRU }\end{array}$ & 3.52 & Agree \\
\hline 5 & $\begin{array}{l}\text { The technology on LRU has } \\
\text { always been revised and updated }\end{array}$ & 4.06 & $\begin{array}{l}\text { Strongly } \\
\text { Agree }\end{array}$ \\
\hline 6 & $\begin{array}{l}\text { The cost for maintaining LRU in } \\
\text { house is cheaper than outsourcing } \\
\text { to } \quad \text { Singapore }\end{array}$ & 4.02 & $\begin{array}{c}\text { Strongly } \\
\text { Agree }\end{array}$ \\
\hline 7 & $\begin{array}{l}\text { The only LRU centre available } \\
\text { is provided previously by } \\
\text { MAS (now known as MAB) }\end{array}$ & 4.14 & $\begin{array}{l}\text { Strongly } \\
\text { Agree }\end{array}$ \\
\hline 8 & $\begin{array}{l}\text { There are no other known LRUC } \\
\text { in Malaysia besides MAS (MAB) }\end{array}$ & 3.74 & Agree \\
\hline 9 & $\begin{array}{l}\text { The maintenance of LRU needs to } \\
\text { be maintained and repaired by } \\
\text { license engineer ap- } \\
\text { proved by DCA }\end{array}$ & 3.52 & Agree \\
\hline 10 & $\begin{array}{l}\text { LRU centre is a business oppor- } \\
\text { tunity in Malaysia }\end{array}$ & 4.17 & $\begin{array}{l}\text { Strongly } \\
\text { Agree }\end{array}$ \\
\hline
\end{tabular}

Table 6: Problem(s) raised without the existence of an LRUC

\begin{tabular}{|c|c|c|c|}
\hline No. & Statement & Mean & Indicator \\
\hline 1 & $\begin{array}{l}\text { There is rarely any specialist on LRU } \\
\text { maintenance and repair in most aviation } \\
\text { companies }\end{array}$ & 3.80 & Agreed \\
\hline 2 & $\begin{array}{l}\text { It is difficult to find an LRU } \\
\text { specialist in Malaysia }\end{array}$ & 4.05 & Agreed \\
\hline 3 & $\begin{array}{l}\text { Most companies do not have } \\
\text { sufficient assets to establish an LRUC } \\
\text { in Malaysia }\end{array}$ & 4.02 & Agreed \\
\hline 4 & $\begin{array}{l}\text { Many aircraft need to be grounded due } \\
\text { to defect on LRUs }\end{array}$ & 3.80 & Agreed \\
\hline 5 & $\begin{array}{l}\text { Updates and revisions on LRU technol- } \\
\text { ogy have been quite slow in the local } \\
\text { aviation community }\end{array}$ & 3.86 & Agreed \\
\hline 6 & $\begin{array}{l}\text { The cost for maintaining LRU is high } \\
\text { due to outsourcing }\end{array}$ & 4.24 & Agreed \\
\hline 7 & $\begin{array}{l}\text { The only outsource company having } \\
\text { LRUC is MAS (MAB) }\end{array}$ & 4.24 & Agreed \\
\hline 8 & $\begin{array}{l}\text { MAS (MAB) cannot serve other Malay- } \\
\text { sian aviation companies' LRU } \\
\text { maintenance requests. }\end{array}$ & 4.03 & Agreed \\
\hline 9 & $\begin{array}{l}\text { The number of specialists with DCA } \\
\text { license is limited }\end{array}$ & 3.67 & Agreed \\
\hline 10 & $\begin{array}{l}\text { Nobody is taking advantage to establish } \\
\text { an LRUC as business opportunity in } \\
\text { Malaysia }\end{array}$ & 4.09 & Agreed \\
\hline
\end{tabular}

\section{Conclusion}

As a conclusion, LRUC is in dire need in Malaysia because almost all aviation companies do not have LRU personnel, workshop and equipment to maintain and also repair their LRUs in-house. More discussions and memorandum of agreements will benefit not only the aircraft maintenance industry but also potential development and improvement for other relevant bodies and agencies in Malaysia, particularly Civil Aviation Authority Malaysia (CAAM), Malaysian airports [12], approved training organizations, commercial airlines, etc. With that, UniKL MIAT will proceed with the necessary documentation to establish an LRUC in the near future.

\section{References}

[1] Department of Civil Aviation Malaysia (1996), www.dca.gov.my/ wp-content/uploads/2015/02/Mcar96 -3.pdf

[2] Kulkarni P (2013), A literature review on training and development and quality of work life. Journal of Arts, Science and Commerce IV(2), 136-143

[3] Khairuddin MH, Yahya MY \& Johari MK (2017), Critical needs for piston engine overhaul centre in Malaysia. IOP Conference Series: Materials Science and Engineering 270, 012013

[4] Bhatia S \& Arora E (2017), Workplace spirituality: An employeremployee perspective.International Journal of Innovative Research and Development 6(1), 106-111

[5] Leonard B (2007), Technology and the future evolution of the ATC system. www.princeton.edu/ ota/disk3/1982/8202/820207.pdf

[6] Safi A (2015), VHF communication basics. www.slideshare.net/ah madsajjadsafi/communication-basics-part-3

[7] Ames J, Chang N \& Magill T (1984), Development and testing of adaptive $\mathrm{HF}$ radio techniques. http://www.dtic.mil

[8] Flight Mechanic (2017), www.flight-mechanic.com

[9] Dandotiya R, Yuan F \& Kumar U (2008), Optimal maintenance decision for line reparable units (LRU's) for an aircraft system A conceptual approach. OPSEARCH, 291-302.

[10] Department of Civil Aviation Malaysia (2018), www.dca.gov.my

[11] Department of Civil Aviation Malaysia (2002), http://www.dca.gov. my/wp-content/uploads/2015/02/AN57A.pdf

[12] Bardai AM, Er A, Johari MK \& Mohd Noor AA (2017), A review of Kuala Lumpur International Airport (KLIA) as a competitive South-East Asia hub. IOP Conference Series: Materials Science and Engineering 270, 012039 